\title{
BamH1 POLYMORPHISM IN THE CHINESE, MALAYS, AND INDIANS IN SINGAPORE AND ITS APPLICATION IN THE PRENATAL DIAGNOSIS OF $\beta$-THALASSEMIA
}

\author{
Jin Ai Mary Anne TAN, * Sin Hock John TAY, \\ Kow Yin Shirley KHAM, and Hock Boon Wong \\ Department of Pediatrics, National University of Singapore, \\ Lower Kent Ridge Road, Singapore 0511
}

\begin{abstract}
Summary The distribution of restriction fragment length polymorphism (RFLP) at the BamH1 site of the $\beta$-globin gene was investigated in the Chinese, Indian, and Malay race in Singapore. The sample comprised of 183 normal individuals and $35 \beta$-thalassemia carriers in which 13 were couples with at least one $\beta$-major child. The results from this study indicate that $B a m \mathrm{H} 1$ polymorphism will be informative in $22 \%$ of pregnancies at risk for $\beta$-thalassemia major in Chinese, $19 \%$ in Malays and $7 \%$ in Indians. In prenatal diagnosis using Bam $\mathrm{H} 1$ polymorphism for one $\beta$-major affected family, the fetus was diagnosed to be normal or $\beta$ carrier. The validity of $B a m \mathrm{H} 1$ polymorphism in the exclusion of $\beta$ thalassemia major was subsequently confirmed at birth by globin chain biosynthesis.
\end{abstract}

Key Words $\quad$ RFLP, BamH1, prenatal diagnosis, $\beta$-thalassemia

\section{INTRODUCTION}

The $\beta$-thalassemias are characterized by a reduced output of $\beta$-chains of hemoglobin. Couples who are $\beta$-thalassemia carriers have a $25 \%$ risk of producing a homozygous $\beta$-thalassemic child (Weatherall, 1983).

Prenatal diagnosis of $\beta$-thalassemias has been carried out using globin chain biosynthesis (Modell, 1983), DNA polymorphisms (Boehm et al., 1983; Huang et al., 1985) and oligonucleotide probes (Rosatelli et al., 1985; Cai et al., 1988). The Bam $\mathrm{H1}$ polymorphism located at 3' to the $\beta$-globin gene has been used for prenatal diagnosis of homozygous $\beta$-thalassemia in Sardinians (Kan et al., 1980) and Chinese (Chan et al., 1984). The presence of the Bam $\mathrm{H} 1$ polymorphic site produces a 22 $\mathrm{kb}$ fragment instead of the $9.3 \mathrm{~kb}$ fragment in normal and $\beta$-thalassemia carriers

Received January 19, 1993; Revised version accepted June 21, 1993.

*To whom correspondence should be addressed. 
while homozygotes produce only the $9.3 \mathrm{~kb}$ Bam $\mathrm{H} 1$ fragment. Therefore presence of the $22 \mathrm{~kb}$ fragment indicates a normal or $\beta$-thalassemia trait and excludes $\beta$-major. The authors present here the distribution of the Bam $\mathrm{H} 1$ polymorphism in normal individuals and those heterozygous and homozygous for $\beta$-thalassemia gene in the Chinese, Indians, and Malays in Singapore. Bam Hl polymorphism at the $\beta$-globin gene region has not been studied before in the Indian and Malay race.

\section{MATERIALS AND METHODS}

Sample. The sample comprised of 80 Chinese (57 normals, 18 $\beta$-carriers, 5 homozygotes), 50 Indians ( 45 normals, 3 carriers, 2 homozygotes), and 53 Malays (32 normal, 14 carriers, and 7 homozygotes). Thirteen families with at least one $\beta$-major child each were studied. One family requested prenatal diagnosis at 10 weeks of gestation.

Chorionic villi (CV) was obtained at 10 weeks gestation by a transabdominal approach under ultrasound guidance. DNA extraction from white blood cells and CV was carried out as previously described (Tan et al., 1989).

DNA study. DNA $(10 \mu \mathrm{g})$ was digested with BamH1 (Amersham International, England), size fractionated in $0.8 \%$ agarose and transferred onto Hybond$\mathrm{N}$ membrane (Amersham) by Southern blotting (Southern, 1975). The filter was hybridized overnight with an $\alpha-32 \mathrm{P}$ dCTP labeled $4.3 \mathrm{~kb}$ Pst 1 fragment of the $\beta$-globin gene (Feinberg and Vogelstein, 1983) and then washed under stringent conditions before autoradiography.

Globin chain biosynthesis. Cord blood was obtained at birth in preservativefree heparin tubes. Globin was labeled with [ $\left.{ }^{3} \mathrm{H}\right]$ leucine (Alter, 1983) and globin chains separated by CM-sepharose chromatography (Wong et al., 1988).

\section{RESULTS AND DISCUSSION}

Figure 1 shows the three BamH1 genotypes: $9.3 / 9.3,9.3 / 22$, and $22 / 22 \mathrm{~kb}$ patterns. The normal genotype (9.3/9.3) was seen in wells $4,5,7,8,9$, and 13 . The variant $9.3 / 32 \mathrm{~kb}$ pattern was observed in wells 3,10 , and 12 and the variant $22 / 22 \mathrm{~kb}$ pattern was observed in well 14 . DNA from normal individuals or $\beta$ thalassemia carriers digested with $B a m H 1$ produced all three genotypes. In contrast, DNA from all $\beta$-major patients produced only the $9.3 / 9.3 \mathrm{~kb}$ pattern. Table 1 shows the distribution of BamH1 fragments containing the $3^{\prime} \beta$-globin in the three races in Singapore. The $22 \mathrm{~kb} \mathrm{BamH1}$ site found in $22 \%$ of Chinese here was slightly lower than that observed in Hong Kong (29\%, Chan et al., 1984). The prevalence of the site was 0.19 in the Malays and 0.07 in Indians.

Thirteen families with homozygous $\beta$-thalassemia were studied and six families showed the polymorphic BamH1 site. In the prenatal diagnosis for $\beta$-thalassemia, 


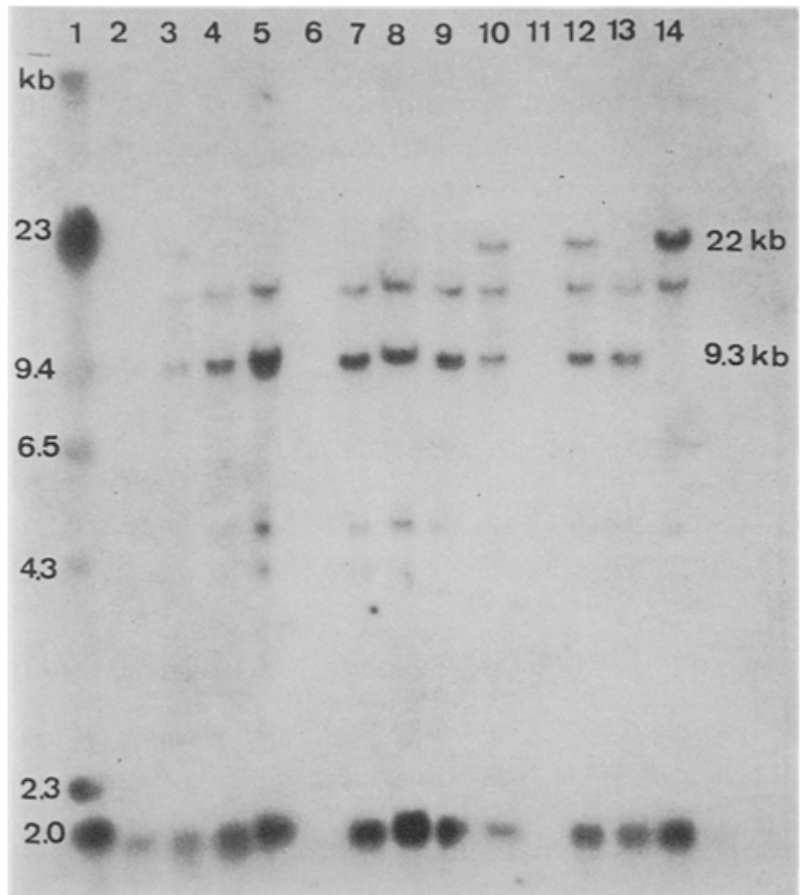

Fig. 1. Autoradiograph of BamH1 digested DNA hybridized with ${ }^{32}$ P-labeled $\beta$-globin gene probe.

lane $4,5,7,8,9,13: 9.3 / 9.3 \mathrm{~kb}$ pattern

lane $3,10,12 \quad: 9.3 / 22 \mathrm{~kb}$ pattern

lane $14 \quad: 22 / 22 \mathrm{~kb}$ pattern

Table 1. Distribution of the polymorphic $22 \mathrm{~kb} \mathrm{BamH1}$ fragment in three racial groups in Singapore.

\begin{tabular}{|c|c|c|c|c|c|c|}
\hline & \multirow[b]{2}{*}{$\mathrm{n}$} & \multicolumn{3}{|c|}{ Bam $\mathrm{H} 1$ pattern } & \multicolumn{2}{|c|}{ Prevalence } \\
\hline & & $9.3 / 9.3$ & $9.3 / 22$ & $22 / 22$ & 9.3 & 22 \\
\hline \multicolumn{7}{|l|}{ Normal } \\
\hline Chinese & 57 & 37 & 15 & 5 & 0.78 & 0.22 \\
\hline Indian & 45 & 40 & 4 & 1 & 0.93 & 0.07 \\
\hline Malay & 32 & 24 & 4 & 4 & 0.81 & 0.19 \\
\hline \multicolumn{7}{|l|}{$\beta$-carriers } \\
\hline Chinese & 18 & 14 & 4 & 0 & 0.89 & 0.11 \\
\hline Indian & 3 & 2 & 1 & 0 & 0.83 & 0.17 \\
\hline Malay & 14 & 13 & 1 & 0 & 0.96 & 0.04 \\
\hline \multicolumn{7}{|c|}{$\beta$-homozygotes } \\
\hline Chinese & 5 & 5 & 0 & 0 & 1 & 0 \\
\hline Indian & 2 & 2 & 0 & 0 & 1 & 0 \\
\hline Malay & 7 & 7 & 0 & 0 & 1 & 0 \\
\hline
\end{tabular}

Vol. 38, No. 3, 1993 
DNA from the fetus at risk produced both the 9.3 and $22 \mathrm{~kb}$ fragments indicating that the fetus was not a $\beta$-thalassemia major. The absence of $\beta$-major disease in the fetus was confirmed by globin chain biosynthesis using cord blood at birth.

The $22 \mathrm{~kb}$ BamHl polymorphic site can be utilized in prenatal diagnosis in families where one parent has the polymorphic $22 \mathrm{~kb}$ fragment. Our results showed the site to be informative in $22 \%$ of pregnancies at risk for $\beta$-major in Chinese, $19 \%$ in Malays, and $7 \%$ in Indians.

\section{REFERENCES}

Alter BP (1983): Antenatal diagnosis using fetal blood. In: Weatherall DJ (ed). Methods in hematology. The thalassaemias. Churchill Livingstone, Edinburgh, pp 114-133

Boehm CD, Antonarakis SE, Philips JA, Stetten G, Kazazian HH Jr (1983): Prenatal diagnosis using DNA polymorphisms. Report of 95 pregnancies at risk for sickle cell disease or $\beta$-thalassemia. New Engl J Med 308: 1054-1058

Cai SP, Zhang JZ, Huang DH, Wang ZX, Kan YW (1988): A simple approach to prenatal diagnosis of $\beta$-thalassemia in a geographic area where multiple mutations occur. Blood 71: $1357-$ 1360

Chan V, Leung NK, Chan TK, Ghosh A, Kan YW, Todd D (1984): BamH1 polymorphism in the Chinese: its potential usefulness in prenatal diagnosis of thalassaemia. $\mathbf{B r}$ Med $\mathbf{J} 289$ : 947948

Feinberg AP, Vogelstein BA (1982): A technique for radiolabelling DNA restriction endonuclease fragments to high specific activity. Anal Biochem 132: 6-13

Huang SZ, Kazazian HH Jr, Waber PG, Luo HY, Cai RL, Wang MQ (1985): $\beta$-Thalassaemia in Chinese. Analysis of polymorphic restriction site haplotypes in the $\beta$-globin gene cluster. Chinese Med J 98: 881-886

Kan YW, Lee KY, Furbetta M, Angius A, Cao A (1980): Polymorphism of DNA sequence in the $\beta$-globin gene region. Application to prenatal diagnosis of $\beta$-thalassaemia in Sardinia. New Engl J Med 302: 185-188

Modell BM (1983): Prevention of the haemoglobinopathies. Br Med Bull 39: 386-391

Rosatelli C, Falchi AM, Tuveri T et al. (1985): Prenatal diagnosis of beta thalassaemia with the synthetic oligomer technique. Lancet i: 241-243

Southern E (1975): Detection of specific sequences among DNA fragments separated by gel electrophoresis. J Mol Biol 98: 503-508

Tan JAMA, Wong HB, Kitzis A, Yap EH, Anandakumar C, Tay JSH (1989): Prenatal diagnosis of homozygous $\alpha^{\circ}$-thalassaemia by direct DNA analysis of chorionic villi in Singapore. Aust Paediatr J 25: 161-163

Wong HB, Tan JAMA, Ong KS, Yeo SH (1988): Prenatal diagnosis of $\beta$-thalassaemia using globin chain biosynthesis. J Singapore Paediatr Soc 30: 113-116

Weatherall DJ (1983): The diagnostic features of the different forms of thalassaemia. In: Weatherall DJ (ed). The thalassaemias. Churchill Livingstone, London, pp 1-26 